\title{
Brain Glucose Transport and Phosphorylation Under Acute Insulin-Induced Hypoglycemia in Mice: An ${ }^{18}$ F-FDG PET Study
}

\author{
Malte F. Alf ${ }^{1,2}$, João M.N. Duarte ${ }^{2,3}$, Roger Schibli ${ }^{1}$, Rolf Gruetter $^{2-4}$, and Stefanie D. Krämer ${ }^{1}$ \\ ${ }^{I}$ Department of Chemistry and Applied Biosciences, Center for Radiopharmaceutical Sciences of ETH-PSI-USZ, Institute of \\ Pharmaceutical Sciences, ETH Zurich, Zurich, Switzerland; ${ }^{2}$ Laboratory of Functional and Metabolic Imaging, Institute of Physics of \\ Biological Systems, Ecole Polytechnique Fédérale de Lausanne, Lausanne, Switzerland; ${ }^{3}$ Department of Radiology, University of \\ Lausanne, Lausanne, Switzerland; and ${ }^{4}$ Department of Radiology, University of Geneva, Geneva, Switzerland
}

\begin{abstract}
We addressed the questions of how cerebral glucose transport and phosphorylation change under acute hypoglycemia and what the underlying mechanisms of adaptation are. Methods: Quantitative ${ }^{18} \mathrm{~F}-\mathrm{FDG}$ PET combined with the acquisition of real-time arterial input function was performed on mice. Hypoglycemia was induced and maintained by insulin infusion. PET data were analyzed with the 2-tissue-compartment model for ${ }^{18} \mathrm{~F}-\mathrm{FDG}$, and the results were evaluated with Michaelis-Menten saturation kinetics. Results: Glucose clearance from plasma to brain $\left(K_{1, \text { glc }}\right)$ and the phosphorylation rate constant increased with decreasing plasma glucose $\left(G_{p}\right)$, in particular at a $G_{p}$ of less than $2.5 \mathrm{mmol} / \mathrm{L}$. Estimated cerebral glucose extraction ratios taking into account an increased cerebral blood flow (CBF) at a $G_{p}$ of less than $2 \mathrm{mmol} / \mathrm{L}$ were between 0.14 and 0.79 . CBF-normalized $K_{1, \text { glc }}$ values were in agreement with saturation kinetics. Phosphorylation rate constants indicated intracellular glucose depletion at $a G_{p}$ of less than $2-3 \mathrm{mmol} / \mathrm{L}$. When brain regions were compared, glucose transport under hypoglycemia was lowest in the hypothalamus. Conclusion: Alterations in glucose transport and phosphorylation, as well as intracellular glucose depletion, under acute hypoglycemia can be modeled by saturation kinetics taking into account an increase in CBF. Distinct transport kinetics in the hypothalamus may be involved in its glucose-sensing function.
\end{abstract}

Key Words: brain glucose metabolism; hypoglycemia; MichaelisMenten kinetics; positron-emission tomography

J Nucl Med 2013; 54:2153-2160

DOI: 10.2967/jnumed.113.122812

\section{B}

lood-borne glucose is the major source of energy for neuronal activity. The rate-determining processes involved in cerebral glucose consumption are glucose transport by hexose transporters (GLUTs) and glucose phosphorylation by hexokinase I (1). Both processes underlie Michaelis-Menten saturation kinetics and can adapt to some extent to chronic hypo- or hyperglycemia. Studies in rats have revealed several possible processes by which the brain

Received Mar. 6, 2013; revision accepted Jul. 11, 2013.

For correspondence or reprints contact either of the following:

João M.N. Duarte, EPFL, Laboratory of Functional and Metabolic Imaging,

$\mathrm{CH}-1015$ Lausanne, Switzerland.

E-mail: joao.duarte@epfl.ch

Stefanie D. Krämer, Institute of Pharmaceutical Sciences, ETH Zürich,

Wolfgang-Pauli-Strasse 10, CH-8093 Zurich, Switzerland.

E-mail: stefanie.kraemer@pharma.ethz.ch

Published online Oct. 24, 2013.

COPYRIGHT (C) 2013 by the Society of Nuclear Medicine and Molecular Imaging, Inc. adapts to glucose deprivation during acute, recurrent, or chronic hypoglycemia. Glucose permeability of the blood-brain barrier (BBB) is increased in models of chronic hypoglycemia. Amplified synthesis and translocation of GLUT1 to the plasma membrane of microvascular endothelial cells have been demonstrated (2-4). In addition, upregulation of neuronal GLUT3 expression is likely to be involved in the brain's adaptation to chronic hypoglycemia $(4,5)$.

Less is known about adaptations under acute hypoglycemia. Cerebral blood flow (CBF) and, therefore, glucose delivery are increased at a plasma glucose level $\left(\mathrm{G}_{\mathrm{p}}\right)$ of less than $2 \mathrm{mmol} / \mathrm{L}(6)$. Increased glucose permeability of the $\mathrm{BBB}$ and in particular translocation of GLUT1 to the cell surface have been suggested as causal mechanisms for elevated transport (6-8). Awareness of acute hypoglycemia is a vital response to low $\mathrm{G}_{\mathrm{p}}$. Hypoglycemia unawareness is a life-threatening problem in patients with type 1 insulin-treated diabetes of long duration and repeated episodes of hypoglycemia. There is ample evidence that the hypothalamus has a glucosesensing function. Although GLUT1 is the major glucose transporter at the BBB in general, some regions in the hypothalamus contain high levels of GLUT2 (9). Two major features of GLUT2 may be involved in glucose sensing. GLUT2 has a higher Michaelis-Menten constant $K_{\mathrm{T}}$ than GLUT1 (10), and a glucose-sensing receptor function was described for an intracellular sequence of GLUT2 (9). In addition, the rate of glucose phosphorylation was found to be altered specifically in the hypothalamus after a history of hypoglycemia (11).

Kinetic modeling of brain uptake of the glucose analog ${ }^{18}$ F-FDG allows investigation of changes in cerebral glucose homeostasis in vivo. So far, ${ }^{18}$ F-FDG PET studies have focused on the cerebral metabolic rate of glucose $\left(\mathrm{CMR}_{\mathrm{glc}}\right)$ in rats. ${ }^{18} \mathrm{~F}-\mathrm{FDG}$ PET on mice rather than rats has a greater potential to address specific questions related to human metabolic and neurologic diseases, as the mouse is the preferred species for transgenic disease models. $\mathrm{CMR}_{\mathrm{glc}}$ can be estimated from PET data without the requirement of a highly time-resolved input function (12). However, $\mathrm{CMR}_{\mathrm{glc}}$ provides no information on the individual contributions of transport and phosphorylation to glucose consumption. In addition, for a correct determination of $\mathrm{CMR}_{\mathrm{glc}}$, the so-called lumped constant (LC) is indispensable, correcting for differences between ${ }^{18} \mathrm{~F}$-FDG and glucose with respect to transport and phosphorylation kinetics, respectively $(13,14)$. LC is often used as a $\mathrm{G}_{\mathrm{p}}$-independent parameter although the relative contributions of transport and phosphorylation may vary, depending on $\mathrm{G}_{\mathrm{p}}$.

The key limiting factor for determining both transport and phosphorylation kinetics in mice is the small blood volume and the resulting difficulty in measuring an adequate arterial input function. 
To overcome this issue, we adapted an earlier protocol for rats (15) to measurements in mice. This protocol is based on an arteriovenous shunt and a coincidence counter to record input functions with a high temporal resolution (16). With this, the rate constants of the single processes, that is, ${ }^{18} \mathrm{~F}$-FDG transport and phosphorylation, are accessible.

Extending our data from normoglycemic mice (16) to data from mice undergoing insulin-induced acute hypoglycemia, we addressed the question of how acute hypoglycemia affects the kinetics of regional glucose transport and phosphorylation in the mouse brain. We evaluated whether the observed alterations are the consequences of saturation kinetics and increased CBF alone or whether additional physiologic adaptations such as alterations in barrier permeability need to be considered to model the data.

\section{MATERIALS AND METHODS}

\section{Animal Preparation}

Animal experiments were in accordance with the Swiss Animal Protection Law and were approved by the Veterinary Office of the Canton Zurich. To exclude strain-specific effects, we included 2 strains. Male $\mathrm{CD} 1(n=10$; weight, $34.2 \pm 2.5 \mathrm{~g}$ [mean $\pm \mathrm{SD}])$ and C57BL/6 $(n=5$, $27.1 \pm 2.8 \mathrm{~g}$ ) mice (Charles River) were housed under standard conditions. Data from non-insulin-treated animals $(n=14)$ were from recent experiments (16). Animals were prepared as described previously for the acquisition of PET/CT and input function (16). Briefly, catheters were inserted into the femoral artery and vein and were connected to form a closed shunt loop, which was guided through a coincidence counter (twilite; Swisstrace) and a peristaltic pump at a constant flow of $120 \mu \mathrm{L} / \mathrm{min}$. Two 3-way valves were used for insulin and ${ }^{18} \mathrm{~F}$-FDG infusion.

\section{Insulin Infusion and Blood Sampling}

Insulin (Actrapid, $1 \mathrm{IU} / \mathrm{mL}$; Novo Nordisk) infusion rates were dependent on the animal weight and the initial and target $G_{p}$ concentrations. For a mouse weighing $30 \mathrm{~g}$, insulin infusion started with $9 \mu \mathrm{L} / \mathrm{min}$ for $1 \mathrm{~min}$ and then was decreased stepwise over $4 \mathrm{~min}$ to a constant rate of $3 \mu \mathrm{L} / \mathrm{min}$. Whole-blood glucose was measured in samples of $5 \mu \mathrm{L}$ with a blood glucose meter (Ascensia; Bayer HealthCare LLC) up to 4 times before the start of the PET scan. Blood glucose levels reached a steady state $10-15$ min after infusion began. A larger arterial blood sample was drawn immediately after the PET scan. Plasma was separated by centrifugation, and $G_{p}$ was measured with a glucose oxidase/reflectance system (Vitros DT60 II; Ortho Clinical Diagnostics).

\section{Imaging}

PET scanning and ${ }^{18} \mathrm{~F}-\mathrm{FDG}$ infusion were started simultaneously when $G_{p}$ had reached a plateau of less than $2.5 \mathrm{mmol} / \mathrm{L}$. The isoflurane dose was adjusted to maintain the respiratory rate at between 75 and $100 \mathrm{bpm}$, and body temperature was kept between $36.5^{\circ} \mathrm{C}$ and $37.3^{\circ} \mathrm{C}$. PET acquisition was performed as described previously with a VISTA eXplore PET/CT scanner (GE Healthcare, 0.9-mm resolution in full width at half maximum in the center of the field of view) (16). PET data were reconstructed to a nominal voxel volume of 0.116 $\mathrm{mm}^{3}$. Whole-blood radioactivity was recorded in real time with the coincidence counter and translated to plasma ${ }^{18} \mathrm{~F}-\mathrm{FDG}$ concentration (16). Injected ${ }^{18} \mathrm{~F}$-FDG doses were $10-15 \mathrm{MBq}$ (40-60 pmol) in 200 $\mu \mathrm{L}$, resulting in plasma ${ }^{18} \mathrm{~F}-\mathrm{FDG}$ concentrations of less than $10 \mathrm{nM}$.

PET/CT images were coregistered with the PMOD software (PMOD Technologies Inc.) to a mouse brain template provided by PMOD. Template volumes of interest were used to generate time-activity curves for the following structures: cerebrum $\left(362 \mathrm{~mm}^{2}\right)$, cortex $\left(149 \mathrm{~mm}^{2}\right)$, striatum $\left(25.8 \mathrm{~mm}^{2}\right)$, hippocampus $\left(25.0 \mathrm{~mm}^{2}\right)$, thalamus $\left(28.2 \mathrm{~mm}^{2}\right)$, hypothalamus $\left(11.6 \mathrm{~mm}^{2}\right)$, and cerebellum $\left(57.2 \mathrm{~mm}^{3}\right)$ (Supplemental Fig. 1; supplemental materials are available at http://jnm.snmjournals.org).

\section{Kinetic Modeling}

Time-activity curves were analyzed by 2 -tissue-compartment ${ }^{18} \mathrm{~F}$ FDG kinetic modeling with PMOD as described previously (16) to determine the clearance $K_{1, \mathrm{FDG}}\left(\mathrm{mL} / \mathrm{min}\right.$ per $\mathrm{cm}^{3}$ tissue) for ${ }^{18} \mathrm{~F}$-FDG transport from plasma to brain and the rate constants $(1 / \mathrm{min}) k_{2, \mathrm{FDG}}$ for reverse transport, $k_{3 \text {,FDG }}$ for ${ }^{18} \mathrm{~F}$-FDG phosphorylation, and $k_{4 \text {,FDG }}$ for dephosphorylation (17). Image data were corrected for blood radioactivity with a fractional cerebral blood volume of $5.5 \%$ (18). The transport rate of glucose from plasma to tissue $\left(\mathrm{T}_{\mathrm{glc}}, \mu \mathrm{mol} / \mathrm{min} / 100 \mathrm{~g}\right)$ was calculated according to Equation 1,

$$
\mathrm{T}_{\mathrm{glc}}=K_{1, \mathrm{FDG}} \times \frac{1}{\mathrm{~L}_{1}} \times \mathrm{G}_{\mathrm{p}} \times \frac{1}{\rho} \times 100=K_{1, \mathrm{glc}} \times \mathrm{G}_{\mathrm{p}} \times \frac{1}{\rho} \times 100,
$$

Eq. 1

with $\mathrm{G}_{\mathrm{p}}$ being in mmol/L and $\rho$ being brain tissue density of $1.04 \mathrm{~g} / \mathrm{cm}^{3}$ (19). $\mathrm{L}_{1}$ is the ratio between $K_{1, \mathrm{FDG}}$ and $K_{1}$ of glucose $\left(K_{1, \mathrm{FDG}} / K_{1, \mathrm{glc}}=\right.$ 1.48). $\mathrm{L}_{1}$ corrects for differences in ${ }^{18} \mathrm{~F}-\mathrm{FDG}$ and glucose transport kinetics and was determined in nonsedated humans at a $G_{p}$ of 3-16 $\mathrm{mmol} / \mathrm{L}$ and was about $10 \%$ lower than estimated for pentobarbitalanesthetized rats (20) (supplemental data).

\section{Influence of $\mathrm{CBF}$ on $\mathrm{K}_{\mathbf{1}, \mathrm{glc}}$ and $\mathrm{T}_{\mathrm{glc}}$}

The extraction ratio of glucose from plasma to brain tissue $\left(\mathrm{E}_{\mathrm{glc}}\right)$ was estimated with Equation 2. The permeability-surface area product $\left(\mathrm{PS}_{\mathrm{glc}}\right.$ ), that is, $K_{1, \mathrm{glc}}$ values at infinite $\mathrm{CBF}$, was extrapolated with Equation 3. Hypothetical $K_{1, \text { glc }}$ at a given CBF was estimated from $\mathrm{PS}_{\mathrm{glc}}$ with Equation 4 (21):

$$
\begin{aligned}
\mathrm{E}_{\mathrm{glc}} & =\frac{K_{1, \mathrm{glc}}}{\mathrm{CPF}} \\
\mathrm{PS}_{\mathrm{glc}} & =-\mathrm{CPF} \times \ln \left(1-\mathrm{E}_{\mathrm{glc}}\right), \\
K_{1, \mathrm{glc}} & =\mathrm{CPF} \times\left(1-e^{-\frac{\mathrm{PS}_{\mathrm{glc}}}{\mathrm{CPF}}}\right),
\end{aligned}
$$

with CPF being cerebral plasma flow, that is, the product of [1 hematocrit $=0.56](22)$ and $\mathrm{CBF}$ in $\mathrm{mL} / \mathrm{min} / \mathrm{cm}^{3}$. At a $\mathrm{G}_{\mathrm{p}}$ of more than $2 \mathrm{mmol} / \mathrm{L}$, a CBF of $1.30 \mathrm{~mL} / \mathrm{min} / \mathrm{cm}^{3}$ (averaged from (23), excluding corpus callosum) was used except for the hypothalamus, for which a CBF of $0.86 \mathrm{~mL} / \mathrm{min} / \mathrm{cm}^{3}$ was used (24). An increase in CBF by $57 \%$ (supplemental data: $0 \%-100 \%$ ) was assumed at a $\mathrm{G}_{\mathrm{p}}$ of less than $2 \mathrm{mmol} / \mathrm{L}(6,25)$.

\section{Michaelis-Menten Saturation Kinetics}

To estimate Michaelis-Menten parameters, average $G_{p}$ along the capillary $\left(\mathrm{G}_{\mathrm{p}}^{\prime}\right)$ was calculated from the arterial $\mathrm{G}_{\mathrm{p}}$ with Equation 5 . The correction was not applied to $G_{p}$ in Equation 1, because a similar reduction in the concentration of ${ }^{18} \mathrm{~F}-\mathrm{FDG}$ (input function) and $\mathrm{G}_{\mathrm{p}}$ along the capillary was assumed. $K_{1, \text { FDG }}$ is thus underestimated by a factor similar to $\mathrm{G}_{\mathrm{p}}{ }_{\mathrm{p}} / \mathrm{G}_{\mathrm{p}}$.

$$
\mathrm{G}_{\mathrm{p}}^{\prime}=\mathrm{G}_{\mathrm{p}}\left[1-\mathrm{E}_{\mathrm{glc}}\left(1-e^{-1}\right)\right]
$$

Michaelis-Menten functions as shown in Equations 6 and 7 (and the supplemental data) were fit to $K_{1, \text { glc }}$ and $\mathrm{T}_{\text {glc }}$, respectively, by leastsquares regression analysis (SigmaPlot, version 12.5; Systat Software Inc.). $K_{1, \text { glc }}$ values at a $\mathrm{G}_{\mathrm{p}}$ of less than $2 \mathrm{mmol} / \mathrm{L}$ were normalized to physiologic $\mathrm{CBF}$ with Equations 2-4 to exclude the effect of increased 
CBF. Estimated parameters were the maximal capacity $\left(\mathrm{T}_{\max }\right), \mathrm{G}^{\prime}{ }_{\mathrm{p}}$ at half $\mathrm{T}_{\max }\left(K_{\mathrm{T}}\right)$, and $\mathrm{T}_{\max } / K_{\mathrm{T}}\left(K_{1, \text { glc }}{ }^{1 \text { st }}\right.$ order $)$ for glucose transport. Multiplication of Equation 6 by $\mathrm{G}_{\mathrm{p}}$ reveals Equation 7 .

$$
\begin{gathered}
K_{1, \mathrm{glc}}=\frac{\mathrm{T}_{\mathrm{max}}}{K_{\mathrm{T}, \mathrm{glc}}+\mathrm{G}_{\mathrm{p}}^{\prime}}=\frac{K_{1, \mathrm{glc}}^{1 \mathrm{st} \text { order }}}{1+\frac{\mathrm{G}_{\mathrm{p}}^{\prime}}{K_{\mathrm{T}, \mathrm{glc}}}} \\
\mathrm{T}_{\mathrm{glc}}=\frac{\mathrm{T}_{\max } \times \mathrm{G}_{\mathrm{p}}^{\prime}}{K_{\mathrm{T}, \mathrm{glc}}+\mathrm{G}_{\mathrm{p}}^{\prime}} \times \frac{1}{\rho} \times 100
\end{gathered}
$$

Equation 6 was used correspondingly to analyze $k_{3, \mathrm{glc}}\left(\mathrm{L}_{3}=\right.$ $k_{3, \mathrm{FDG}} / k_{3, \mathrm{glc}}=0.38(20)$ ). $\mathrm{T}_{\max }$ was replaced by $\mathrm{V}_{\max } \times \mathrm{G}_{\mathrm{p}} / \mathrm{G}_{\mathrm{i}}$, the maximal phosphorylation velocity, where $G_{p} / G_{i}$ is the correction factor for the ratio between $G_{p}$ and intracellular glucose concentration $\left(\mathrm{G}_{\mathrm{i}}\right) . K_{\mathrm{T}}$ was replaced by $K_{\mathrm{M}}$, that is, $\mathrm{G}_{\mathrm{p}}^{\prime}$ at half maximal $\mathrm{V}_{\max } \times \mathrm{G}_{\mathrm{p}} / \mathrm{G}_{\mathrm{i}}$. Fitting for $\left(\mathrm{V}_{\max } \times \mathrm{G}_{\mathrm{p}} / \mathrm{G}_{\mathrm{i}}\right) / K_{\mathrm{M}}$ revealed $k_{3, \mathrm{glc}}{ }^{1 \text { st }}$ order . The ${ }^{18} \mathrm{~F}$-FDG uptake rate constant $\left(K_{\mathrm{FDG}}\right)$, the relative volume of distribution $\left(\mathrm{V}_{\mathrm{D}}\right)$, and $\mathrm{CMR}_{\text {glc }}$ were calculated according to Equations $8-10$ with LCs as described below.

$$
\begin{aligned}
K_{\mathrm{FDG}} & =\frac{K_{1, \mathrm{FDG}} \times k_{3, \mathrm{FDG}}}{k_{2, \mathrm{FDG}}+k_{3, \mathrm{FDG}}} \\
\mathrm{V}_{\mathrm{D}} & =\frac{K_{1, \mathrm{FDG}}}{k_{2, \mathrm{FDG}}}+\frac{K_{1, \mathrm{FDG}} \times k_{3, \mathrm{FDG}}}{k_{2, \mathrm{FDG}} \times k_{4, \mathrm{FDG}}} \\
\mathrm{CMR}_{\mathrm{glc}} & =\frac{K_{\mathrm{FDG}} \times \mathrm{G}_{\mathrm{p}}}{\mathrm{LC}}
\end{aligned}
$$

LC

The $\mathrm{CMR}_{\text {glc }}$ of the cerebrum was estimated with $3 \mathrm{LCs}$ : LC1, an invariable LC of $0.6(26,27)$; $L C 2$, a G $\mathrm{G}_{\mathrm{p}}$-adjusted LC derived from the values reported for awake rats by Suda et al. (13) (for this purpose, we multiplied the LC values in rats by a factor of 1.35 , to reach an LC of 0.6 on average in normoglycemic animals); and LC3, the LC derived from experimental parameters as proposed by Backes et al. and shown in Equation $11(28)$, assuming $\mathrm{L}_{1}=\mathrm{L}_{2}=1.48$ and $\mathrm{L}_{3}=0.38(20)$.

$$
\mathrm{LC} 3=\frac{\frac{K_{1, \mathrm{FDG}} \times k_{3, \mathrm{FDG}}}{k_{2, \mathrm{FDG}} \times k_{3, \mathrm{FDG}}}}{\frac{\mathrm{L}_{1} \times K_{1, \mathrm{FDG}} \times \mathrm{L}_{3} \times k_{3, \mathrm{FDG}}}{\mathrm{L}_{2} \times k_{2, \mathrm{FDG}}+\mathrm{L}_{3} \times k_{3, \mathrm{FDG}}}}=\mathrm{L}_{1} \times\left\{\frac{\mathrm{L}_{3}}{\mathrm{~L}_{2}}+\left(1-\frac{\mathrm{L}_{3}}{\mathrm{~L}_{2}}\right) \times \frac{K_{\mathrm{FDG}}}{K_{1, \mathrm{FDG}}}\right\}
$$

Eq. 11

\section{Estimation of Intracellular Glucose Concentration}

The intracellular glucose concentration $\mathrm{G}_{\mathrm{i}}$ was iteratively estimated from $\mathrm{G}_{\mathrm{p}}$ according to Equation 12 .

$$
\mathrm{G}_{\mathrm{i}}=\mathrm{G}_{\mathrm{p}} \times \frac{K_{1, \mathrm{glc}}}{k_{3, \mathrm{glc}}+k_{2, \mathrm{glc}}}=\mathrm{G}_{\mathrm{p}} \times \frac{\frac{\mathrm{T}_{\max }}{K_{\mathrm{T}, \mathrm{glc}}+\mathrm{G}_{\mathrm{p}}}}{\frac{\mathrm{v}_{\max } \times \mathrm{G}_{\mathrm{p}} / \mathrm{G}_{\mathrm{i}}}{\frac{\mathrm{G}_{\mathrm{p}} / \mathrm{G}_{\mathrm{i}}(\mathrm{at}}{\left.K_{\mathrm{M}}=5 \mathrm{mmol} / \mathrm{m}\right)}}+\frac{\mathrm{T}_{\max }}{K_{\mathrm{T}, \mathrm{glc}}+\mathrm{G}_{\mathrm{i}}}}
$$

$\mathrm{G}_{\mathrm{p}} / \mathrm{G}_{\mathrm{i}}$ at a $\mathrm{G}_{\mathrm{p}}$ of $5 \mathrm{mmol} / \mathrm{L}$, where hexokinase $\mathrm{I}$ is saturated but not GLUT1, was determined by iteration; $K_{\mathrm{M}}$ was $0.04 \mathrm{mmol} / \mathrm{L}$ (29). All other parameters were fit as described above.

\section{Statistics}

The influence of brain region on single rate constants, $K_{\mathrm{FDG}}$, and $\mathrm{CMR}_{\text {glc }}$ was assessed with repeated-measures ANOVA with brain region as the within-subject factor (cortex, striatum, hippocampus, thalamus, cerebellum, and hypothalamus, i.e., $d f=5$ ). Significant $F$ values are reported. For the purpose of post hoc testing with 2-tailed, homoscedastic $t$ tests, data from regions with a significant within-subject effect were separated into a hypoglycemic group $\left(\mathrm{G}_{\mathrm{p}}<2.5 \mathrm{mmol} / \mathrm{L}\right.$, corresponding to $\left.\mathrm{G}_{\mathrm{p}}^{\prime}<2 \mathrm{mmol} / \mathrm{L}\right)$ and a normoglycemic group $\left(\mathrm{G}_{\mathrm{p}}>2.5\right.$ $\mathrm{mmol} / \mathrm{L}$ ). All data are shown with associated SD unless otherwise stated. The supplemental data report $R^{2}$.

\section{RESULTS}

The insulin-clamp protocol resulted in a $\mathrm{G}_{\mathrm{p}}$ of $1.9 \pm 0.3 \mathrm{mmol} / \mathrm{L}$ ( $n=14$, plus 1 outlier with $3.8 \mathrm{mmol} / \mathrm{L}$ because the initial infusion rate was accidentally reduced). ${ }^{18} \mathrm{~F}-\mathrm{FDG}$ plasma clearance was faster in hypoglycemic than normoglycemic animals (Fig. 1).

\section{Influence of CBF on Cerebral Glucose Transport}

As shown in Figure $2 \mathrm{~A}, K_{1, \mathrm{glc}}\left(K_{1, \mathrm{FDG}} / \mathrm{L}_{1}\right)$ was highest at a low $G_{p}$ and decreased with increasing $G_{p}$. $T_{\text {glc }}$ followed a typical saturation function (Supplemental Fig. 2). Because CBF increases abruptly at a $G_{p}$ of less than $2 \mathrm{mmol} / \mathrm{L}$ in rats $(6,25)$, we first investigated to what extent a similar increase in $\mathrm{CBF}$ would affect $K_{1, \mathrm{glc}}$. We assumed a $57 \%$ increase in $\mathrm{CBF}$ at a $\mathrm{G}_{\mathrm{p}}$ of less than $2 \mathrm{mmol} / \mathrm{L}$ from 1.30 to $2.04 \mathrm{~mL} / \mathrm{min} / \mathrm{cm}^{3}(6,23,24)$ and estimated the corresponding hypothetic $K_{1, \mathrm{glc}}$ at $1.30 \mathrm{~mL} / \mathrm{min} / \mathrm{cm}^{3}$ with Equations 2-4. Figure $2 \mathrm{~A}$ and Supplemental Figure 3 show the uncorrected and CBF-normalized $K_{1, \mathrm{glc}}$ values. At a $\mathrm{G}_{\mathrm{p}}$ of less than $2 \mathrm{mmol} / \mathrm{L}\left(\mathrm{CBF}, 2.04 \mathrm{~mL} / \mathrm{min} / \mathrm{cm}^{3}\right)$, PS ranged from 0.22 to $0.80 \mathrm{~mL} / \mathrm{min} / \mathrm{cm}^{3}(0.40 \pm 0.19)$; at a $\mathrm{G}_{\mathrm{p}}$ of $2-3 \mathrm{mmol} / \mathrm{L}(\mathrm{CBF}$, $\left.1.30 \mathrm{~mL} / \mathrm{min} / \mathrm{cm}^{3}\right)$, from 0.24 to $0.41(0.33 \pm 0.06)$; and at a $\mathrm{G}_{\mathrm{p}}$ of more than $3 \mathrm{mmol} / \mathrm{L}$, from 0.11 to $0.35(0.22 \pm 0.07)$. $\mathrm{E}_{\mathrm{glc}}$ was between 0.14 (highest $\mathrm{G}_{\mathrm{p}}$ ) and 0.79 (lowest $\mathrm{G}_{\mathrm{p}}$ ). The estimated average increase in $K_{1, \mathrm{glc}}, \mathrm{T}_{\mathrm{glc}}$, and $K_{\mathrm{FDG}}$ due to the assumed $57 \%$ increase in $\mathrm{CBF}$ was $9 \%(6 \%-19 \%)$. Doubling the $\mathrm{CBF}$ would result in an estimated average increase of $13 \%$ (7\%-25\%). Simulations for $K_{1, \mathrm{glc}}, \mathrm{E}_{\mathrm{glc}}$, and $\mathrm{PS}_{\mathrm{glc}}$ with $\mathrm{CBF}$ increases of between $0 \%$ and $100 \%$ and 2 different $L_{1}$ values are shown in Supplemental

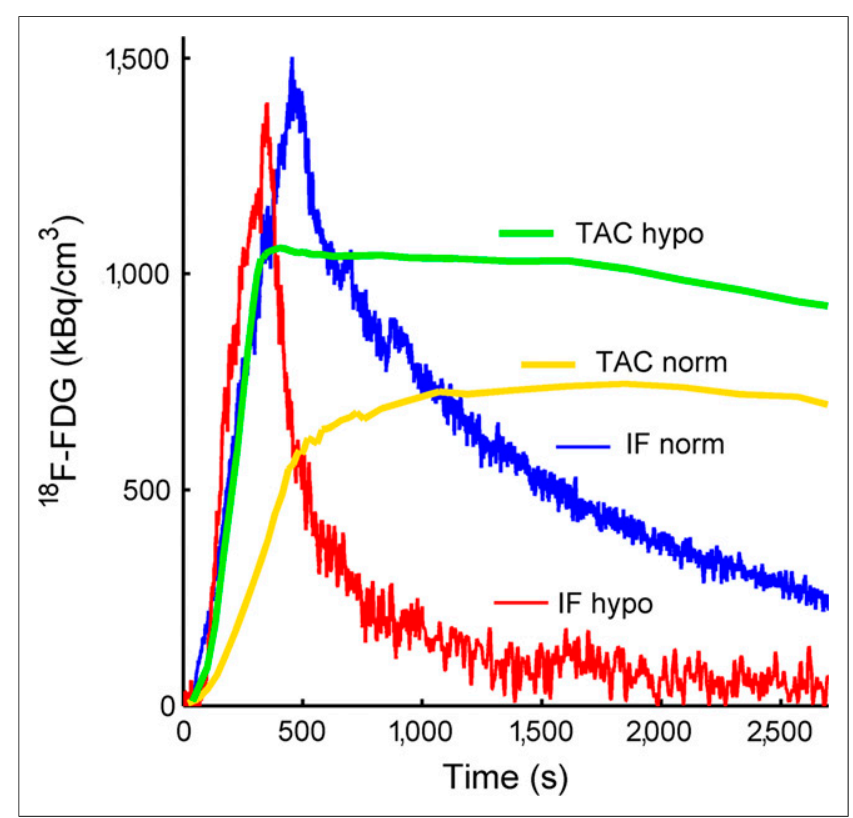

FIGURE 1. Brain time-activity curves and arterial input functions in representative normoglycemic mouse (norm, $G_{p} 6.7 \mathrm{mmol} / \mathrm{L}$ ) and hypoglycemic mouse (hypo, $G_{p} 2.1 \mathrm{mmol} / \mathrm{L}$ ). 


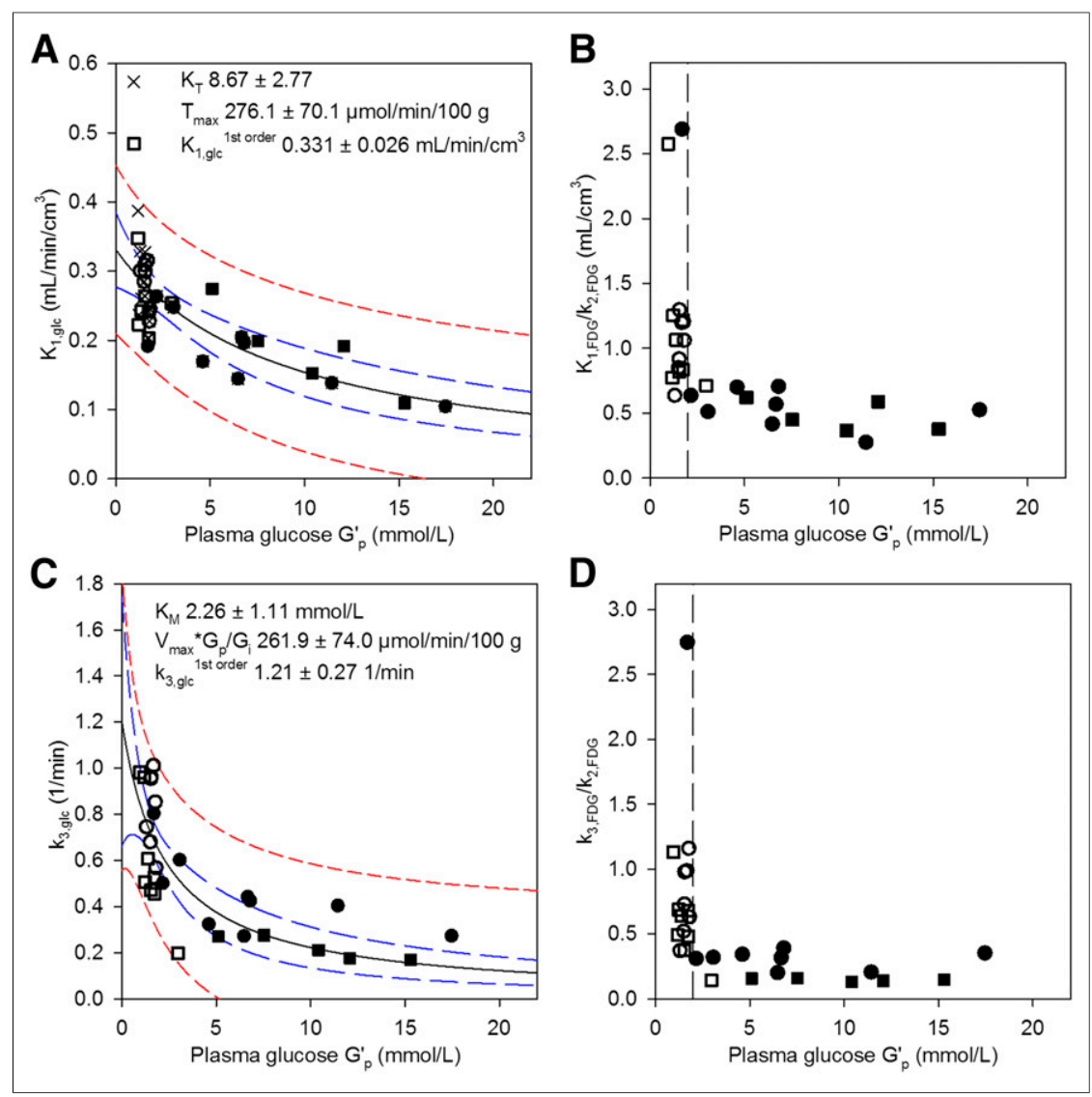

FIGURE 2. (A) Glucose clearance $K_{1, \text { glc }}$ from plasma to brain increases with decreasing $G_{\mathrm{p}} \cdot K_{1, \mathrm{glc}}$ at $\mathrm{G}_{\mathrm{p}}$ of less than $2 \mathrm{mmol} / \mathrm{L}$ was normalized for CBF. (B) ${ }^{18} \mathrm{~F}-\mathrm{FDG}$ partitioning at BBB $\left(K_{1, \mathrm{FDG}} / \mathrm{k}_{2, \mathrm{FDG}}\right)$ with sharp increase below $\mathrm{G}^{\prime}{ }_{\mathrm{p}} 2 \mathrm{mmol} / \mathrm{L}$ (dashed line). (C) $k_{3, \text { glc }}$ sharply increased at $\mathrm{G}^{\prime}{ }_{p}$ of less than $2 \mathrm{mmol} / \mathrm{L}$. (D) Intracellular balance between ${ }^{18} \mathrm{~F}-\mathrm{FDG}$ phosphorylation and efflux $\left(k_{3, \mathrm{FDG}} / k_{2, \mathrm{FDG}}\right)$. Open symbols $=$ insulin-treated; closed symbols $=$ untreated; squares $=57 \mathrm{BL} / 6$ mice; circles $=$ CD1 mice; crosses = not corrected for CBF increase (Supplemental Fig. 3); solid black line = fit with Equation 6 (fit parameters in graph); dashed blue lines $=95 \%$ confidence band; dashed red lines $=95 \%$ prediction band. $R^{2}=0.553(\mathrm{~A}), 0.616(\mathrm{C})$.

Figures 4-6. Supplemental Figure 4 also shows $\mathrm{G}_{\mathrm{p}}^{\prime}$ in relation to $\mathrm{G}_{\mathrm{p}}$. $K_{1, \text { glc }}$ was additionally calculated from $\mathrm{PS}_{\mathrm{FDG}} / \mathrm{L}_{1}$ to evaluate possible artifacts due to CPF-limited transport when $K_{1, \mathrm{FDG}} / K_{1, \mathrm{glc}}$ approaches 1 and $K_{1, \mathrm{FDG}} / \mathrm{L}_{1}$ underestimates $K_{1, \mathrm{glc}}$ (Supplemental Fig. 7).

\section{Influence of Glucose Concentration on Transport and Phosphorylation}

The $K_{1, \mathrm{glc}}$ and $\mathrm{T}_{\mathrm{glc}}$ of the cerebrum were further analyzed with Michaelis-Menten saturation kinetics. To normalize for changes in $\mathrm{CBF}, K_{1, \mathrm{glc}}$ and $\mathrm{T}_{\mathrm{glc}}$ values at a $\mathrm{G}_{\mathrm{p}}$ of less than $2 \mathrm{mmol} / \mathrm{L}$ were estimated for physiologic $\mathrm{CBF}$ as described above. The fit parameters obtained with Equations 6 and 7 are shown in Figure 2A and Supplemental Figures 4, 5, and 7 for CBF increases of between $0 \%$ and $100 \%$ and for $L_{1}$ values of 1.48 (humans) and 1.66 (pentobarbitalanesthetized rats). Depending on $\mathrm{L}_{1}$ and the assumed CBF increase at a $\mathrm{G}_{\mathrm{p}}$ of less than $2 \mathrm{mmol} / \mathrm{L}, K_{\mathrm{t}}$ varied between $6.7 \pm 2.5 \mathrm{mmol} / \mathrm{L}$ $\left(\mathrm{L}_{1}=1.48\right.$, no CBF increase $)$ and $9.3 \pm 2.9 \mathrm{mmol} / \mathrm{L}\left(\mathrm{L}_{1}=1.48\right.$, $100 \% \mathrm{CBF}$ increase) and $\mathrm{T}_{\max }$ between $215 \pm 62 \mu \mathrm{mol} / \mathrm{min} / 100 \mathrm{~g}$ $(\mathrm{L}=1.66$, no $\mathrm{CBF}$ increase $)$ and $289 \pm 71 \mu \mathrm{mol} / \mathrm{min} / 100 \mathrm{~g}(\mathrm{~L}=$ $1.48,100 \% \mathrm{CBF}$ increase).

The efflux rate constant $k_{2}$ scattered between 0.11 and $0.76 / \mathrm{min}$ and did not correlate with $\mathrm{G}_{\mathrm{p}}$ (Supplemental Fig. 8). To visualize the influence of $G_{p}$ on glucose partitioning at the $B B B$, the partition coefficient $K_{1, \mathrm{FDG}} / k_{2, \mathrm{FDG}}$ was plotted versus $\mathrm{G}_{\mathrm{p}}^{\prime}$ (Fig. 2B). Net glucose partitioning from plasma to brain was higher in hypoglycemia than normoglycemia.

Plotting $k_{3, \mathrm{glc}}$ over $\mathrm{G}_{\mathrm{p}}^{\prime}$ showed a sharp increase in $k_{3, \text { glc }}$ at a $\mathrm{G}_{\mathrm{p}}^{\prime}$ of less than 2.0 $\mathrm{mmol} / \mathrm{L}\left(\mathrm{G}_{\mathrm{p}}<2.5 \mathrm{mmol} / \mathrm{L}\right.$; Fig. $\left.2 \mathrm{C}\right)$. Fit parameters of the analysis with Equation 6 are shown in Figure 2C. The intracellular balance between ${ }^{18} \mathrm{~F}$-FDG phosphorylation $\left(k_{3, \mathrm{FDG}} \times \mathrm{G}_{\mathrm{i}}\right)$ and efflux $\left(k_{2, \mathrm{FDG}} \times \mathrm{G}_{\mathrm{i}}\right)$ is shown in Figure $2 \mathrm{D}\left(k_{3, \mathrm{FDG}} / k_{2, \mathrm{FDG}}\right)$. The ratio $k_{3, \mathrm{FDG}} / k_{2, \mathrm{FDG}}$ was not influenced by a $G_{p}$ of above $2.5 \mathrm{mmol} / \mathrm{L}$ but was significantly increased below $2.5 \mathrm{mmol} / \mathrm{L}\left(\mathrm{G}_{\mathrm{p}}^{\prime}<\right.$ $2 \mathrm{mmol} / \mathrm{L})\left(k_{3} / k_{2}=0.24 \pm 0.10, n=14\right.$, at euglycemia, vs. $0.87 \pm 0.60, n=14$, at $\left.\mathrm{G}_{\mathrm{p}}<2.5 \mathrm{mmol} / \mathrm{L} ; P<0.001\right)$. Dephosphorylation of FDG-6-phosphate as described by $k_{4, F D G}$ was significantly different from zero in all animals, with high scattering and no obvious dependence on $\mathrm{G}_{\mathrm{p}}$ (Supplemental Fig. 9). $K_{\mathrm{FDG}}$ and $\mathrm{V}_{\mathrm{D}}$ were derived from the single rate constants and showed respective patterns (Fig. 3 and Supplemental Fig. 10). Both increased when $G_{p}$ was reduced.

Figure 4A shows the LCs as described in the "Materials and Methods" section. When estimated with a fixed $\mathrm{LC}$ of $0.6, \mathrm{CMR}_{\mathrm{glc}}$ was independent of $G_{p}(60 \pm 5$ vs. $51 \pm 6$ $\mu \mathrm{mol} / \mathrm{min} / 100 \mathrm{~g}$ in animals with $\mathrm{a} \mathrm{G}_{\mathrm{p}}$ greater and less than $2.5 \mathrm{mmol} / \mathrm{L}$, respectively) despite the significant increases in $\mathrm{T}_{\text {glc }}$ (Supplemental Fig. 2) and $k_{3, \mathrm{FDG}} \times \mathrm{G}_{\mathrm{p}}$ (not shown) with increasing $\mathrm{G}_{\mathrm{p}}$. However, when LC2 or LC3 was applied, the average $\mathrm{CMR}_{\mathrm{glc}}$ in animals with a $\mathrm{G}_{\mathrm{p}}$ of more than $2.5 \mathrm{mmol} / \mathrm{L}$ was higher in all brain structures examined than the average $\mathrm{CMR}_{\mathrm{glc}}$ in animals with a $\mathrm{G}_{\mathrm{p}}$ of less than $2.5 \mathrm{mmol} / \mathrm{L}$ (all $P<0.003$, Table 1; Figs. 4B and 4C).

\section{Brain-Region-Specific Response to Hypoglycemia}

Brain region had a significant influence on $K_{1, \mathrm{FDG}}(F=7.468, P<$ $0.0005), K_{\mathrm{FDG}}(F=14.346, P<0.0005)$, and $\mathrm{CMR}_{\mathrm{glc}}(F=24.523$, $P<0.0005$ ) but not on $k_{2, \mathrm{FDG}}, k_{3, \mathrm{FDG}}$, and $k_{4, \mathrm{FDG}}($ all $P>0.28)$. $\mathrm{CMR}_{\mathrm{glc}}$ was estimated with LC1 in this analysis. The use of either LC2 or LC3 yielded the same conclusion. Pairwise comparison showed significantly lower $K_{\mathrm{FDG}}$ and $\mathrm{CMR}_{\mathrm{glc}}$ in the hypothalamus and cortex than in any other brain region included in the analysis. In addition, $K_{1, \mathrm{FDG}}$ was lower in the hypothalamus than in any other structure. The differences in $K_{1, \mathrm{FDG}}$ and $K_{\mathrm{FDG}}$ between the hypothalamus and other brain regions were dependent on $\mathrm{G}_{\mathrm{p}}$ : although $K_{1, \mathrm{FDG}}$ and $K_{\text {FDG }}$ were not significantly different between brain regions at a $\mathrm{G}_{\mathrm{p}}$ of more than $2.5 \mathrm{mmol} / \mathrm{L}$, they were less increased (by $15 \%$ and 19\%) under hypoglycemia in the hypothalamus than in other brain structures. The findings in the cortex were similar $(12 \%$ and $17 \%$ less increase for $K_{1, \mathrm{FDG}}$ and $K_{\mathrm{FDG}}$, respectively). These findings are summarized in Table 2, and dot-box plots are shown in Supplemental Figure 11. Differences in $\mathrm{CMR}_{\mathrm{glc}}$ between the regions were independent of $G_{p}$, that is, there was no region $\times G_{p}$ interaction influencing $C_{M R}$ glc 


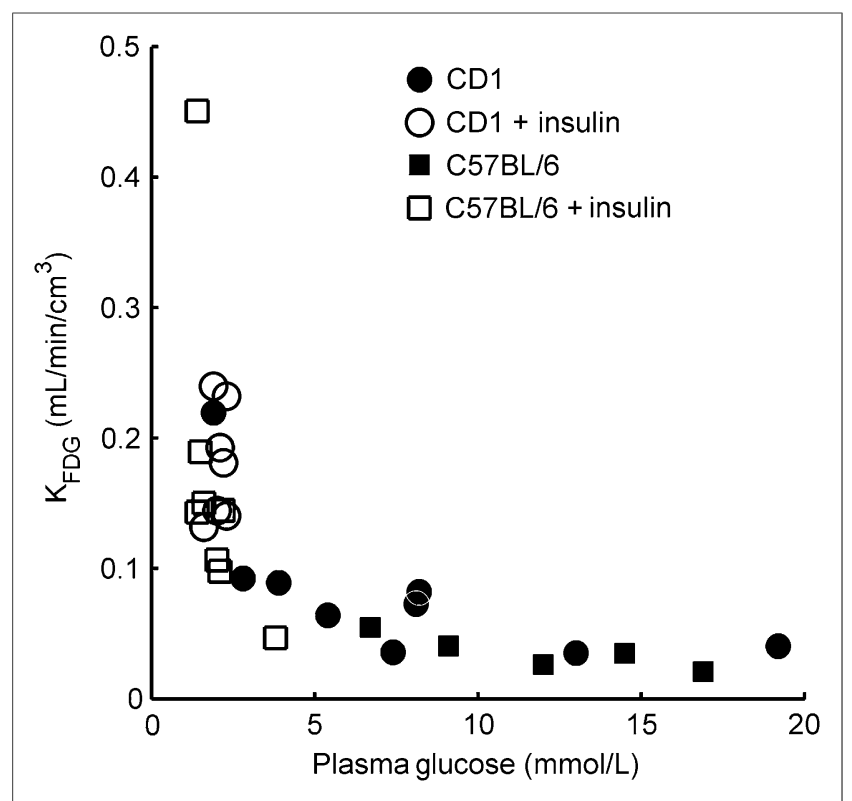

FIGURE 3. $K_{\mathrm{FDG}}$ shows clear dependence on $\mathrm{G}_{\mathrm{p}}$.

$K_{1, \mathrm{glc}}, \mathrm{T}_{\mathrm{glc}}$, and $k_{3, \mathrm{glc}}$ of the respective brain regions were fit to $\mathrm{G}_{\mathrm{p}}^{\prime}$ with Equations 6 and 7. Figure 5, Supplemental Figure 12, and Supplemental Figure 13 show the respective data and fits for glucose transport. As found for the cerebrum (Fig. 2A and Supplemental Fig. 2), transport in the cortex, striatum, hippocampus, and thalamus followed typical saturation kinetics. However, plots from the cerebellum and in particular the hypothalamus had a less pronounced shape of saturation. When fit with both Equation 6 and Equation 7, the hypothalamus had the highest $\mathrm{T}_{\max }$ and $K_{\mathrm{T}}$ at the lowest $K_{1, \mathrm{glc}}{ }^{1 \text { st }}$ order of all studied regions (Fig. 5, Supplemental Fig. 12, and Supplemental Fig. 13). This case was also true when $K_{1, \text { glc }}$ was calculated via $\mathrm{PS}_{\mathrm{glc}} / \mathrm{L}_{1}$ (assuming a $57 \% \mathrm{CBF}$ increase at a $G_{p}$ of less than $2 \mathrm{mmol} / \mathrm{L}$ ) and when normalization was to 1.3 instead of $0.86 \mathrm{~mL} / \mathrm{min} / \mathrm{cm}^{3} \mathrm{CBF}$, indicating that $\mathrm{CBF}$ was not responsible for these observations. The hypothalamus thus has the highest glucose influx at a high $G_{p}$ but the lowest influx under hypoglycemia. Region-specific $k_{3 \text {,glc }}$ as a function of $\mathrm{G}_{\mathrm{p}}{ }_{\mathrm{p}}$ had similar patterns for all investigated brain regions (Supplemental Fig. 14).

\section{Estimation of Intracellular Glucose Concentrations}

The estimated cerebral and hypothalamic $G_{i}$ is shown in Figure 6 as a function of $G_{p}$. Although the estimated $G_{i}$ was similar in both brain regions at a $G_{p}$ of $6.4 \mathrm{mmol} / \mathrm{L}$ (i.e., $G_{i}=2.0 \mathrm{mmol} / \mathrm{L}$ ), it was lower in the hypothalamus than in the cerebrum at a lower $\mathrm{G}_{\mathrm{p}}$ but higher at a $\mathrm{G}_{\mathrm{p}}$ of more than $6.4 \mathrm{mmol} / \mathrm{L}$. The estimated $\mathrm{V}_{\max }$ of phosphorylation (Eq. 12) was 67.4 and $61.0 \mu \mathrm{mol} / \mathrm{min} /$ $100 \mathrm{~g}$ for the cerebrum and hypothalamus, respectively. These values are close to the $\mathrm{CMR}_{\text {glc }}$ values reported in Table 1.

\section{DISCUSSION}

Applying our recently published technique for highly timeresolved monitoring of the ${ }^{18} \mathrm{~F}-\mathrm{FDG}$ input function in mice (16), we investigated glucose transport and phosphorylation kinetics in mouse brain under acute insulin-induced hypoglycemia. We were able to assign the increase in $K_{1, \text { glc }}$ under hypoglycemia to 2 mechanisms. First, our simulations revealed that the expected increase in $\mathrm{CBF}$ at a $\mathrm{G}_{\mathrm{p}}$ of less than $2 \mathrm{mmol} / \mathrm{L}(6,25)$ caused an increase in $K_{1, \mathrm{glc}}, \mathrm{T}_{\mathrm{glc}}$, and $K_{\mathrm{FDG}}$ by $6 \%-19 \%$. The elevation in $\mathrm{CBF}$ as a response to hypoglycemia was thus effectively improving glucose delivery to the brain parenchyma. In fact, as shown by Equations 2-4, the higher the $K_{1 \text {,glc }}$ and therefore $\mathrm{E}_{\mathrm{glc}}$ were, the stronger was the effect of $\mathrm{CBF}$ elevation on glucose transport.

After correction for the effect of CBF elevation at a low $G_{p}$, even when assuming doubling of $\mathrm{CBF}$, cerebral $K_{1, \mathrm{glc}}$ values were still higher at low than high $G_{p}$, and $T_{\text {glc }}$ followed a typical saturation function when plotted against $\mathrm{G}_{\mathrm{p}}^{\prime}$. This finding was expected, as the apparent $K_{\mathrm{T}}$ of GLUT1, the major GLUT isoform at the BBB, lies within the studied range of $\mathrm{G}_{\mathrm{p}}$. The fitted $K_{\mathrm{T}}$ and $\mathrm{T}_{\max }$ were in the range of published values for rats $(1,6,30,31)$. Applying $\mathrm{L}_{1}$ determined with pentobarbital-anesthetized rats instead of $\mathrm{L}_{1}$ determined with nonsedated humans reduced $\mathrm{T}_{\max }$ by about $10 \%$ without affecting $K_{\mathrm{t}}$. We analyzed our data with the standard (irreversible) Michaelis-Menten model, not taking into account product inhibition - that is, transport inhibition or reversible transport at significant glucose levels on the trans side of the transporter (6). This explains the relatively high (apparent) $K_{\mathrm{T}}$ values when compared with experiments under zero trans conditions (6,31). Another simplification was that we assumed only a single mechanism for glucose transport and did not consider additional saturable or nonsaturable routes (32). Regarding $k_{2}$, we

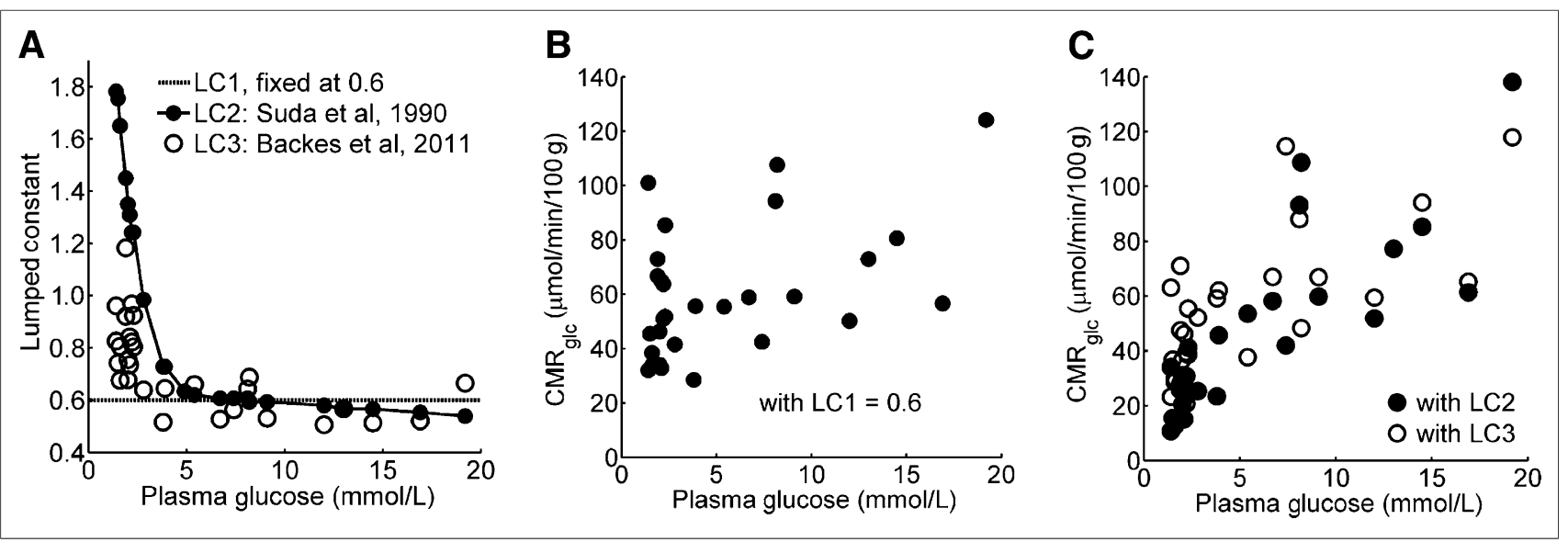

FIGURE 4. (A) LC determined with different methods: constant value of 0.6 (LC1) (26,27); estimated from rat data (LC2) (13); and estimated from L1,

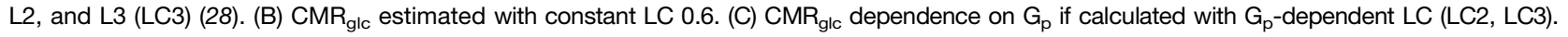


TABLE 1

$\mathrm{CMR}_{\mathrm{glc}}(\mu \mathrm{mol} / \mathrm{min} / 100 \mathrm{~g})$ Grouped by $\mathrm{G}_{\mathrm{p}}$, Estimated with Different LC

\begin{tabular}{|c|c|c|c|c|c|c|c|}
\hline LC & CTX & STR & HIP & THA & HYP & CB & CER \\
\hline \multicolumn{8}{|l|}{$\mathrm{LC} 1=0.6(26)$} \\
\hline $\mathrm{G}_{\mathrm{p}}>2.5 \mathrm{mmol} / \mathrm{L}$ & $56 \pm 29$ & $62 \pm 25$ & $65 \pm 27$ & $66 \pm 29$ & $55 \pm 19$ & $71 \pm 28$ & $66 \pm 27$ \\
\hline $\mathrm{G}_{\mathrm{p}}<2.5 \mathrm{mmol} / \mathrm{L}$ & $48 \pm 16$ & $56 \pm 20$ & $54 \pm 17$ & $55 \pm 22$ & $43 \pm 16$ & $55 \pm 16$ & $55 \pm 21$ \\
\hline \multicolumn{8}{|l|}{ LC2 (13) } \\
\hline $\mathrm{G}_{\mathrm{p}}>2.5 \mathrm{mmol} / \mathrm{L}$ & $56 \pm 34$ & $62 \pm 30$ & $65 \pm 32$ & $65 \pm 35$ & $54 \pm 23$ & $71 \pm 33$ & $66 \pm 32$ \\
\hline $\mathrm{G}_{\mathrm{p}}<2.5 \mathrm{mmol} / \mathrm{L}$ & $20 \pm 7^{\star}$ & $23 \pm 9^{*}$ & $23 \pm 9^{*}$ & $23 \pm 9^{*}$ & $18 \pm 7^{*}$ & $23 \pm 9^{*}$ & $26 \pm 17^{*}$ \\
\hline \multicolumn{8}{|l|}{ LC3 (28) } \\
\hline $\mathrm{G}_{\mathrm{p}}>2.5 \mathrm{mmol} / \mathrm{L}$ & $58 \pm 28$ & $61 \pm 24$ & $63 \pm 24$ & $66 \pm 29$ & $57 \pm 23$ & $70 \pm 30$ & $67 \pm 23$ \\
\hline $\mathrm{G}_{\mathrm{p}}<2.5 \mathrm{mmol} / \mathrm{L}$ & $33 \pm 7^{\star}$ & $37 \pm 9^{\star}$ & $37 \pm 9^{\star}$ & $38 \pm 10^{*}$ & $30 \pm 8^{*}$ & $37 \pm 9^{\star}$ & $38 \pm 11^{*}$ \\
\hline $\begin{array}{l}{ }^{*} P<0.003 \text {, all } t> \\
\text { CTX }=\text { cortex; STF }\end{array}$ & $\begin{array}{l}\text { compared } \\
\text { riatum; HIF }\end{array}$ & $\begin{array}{l}\text { situation w } \\
\text { ppocamp }\end{array}$ & $\begin{array}{l}<2.5 \mathrm{mi} \\
\mathrm{A}=\mathrm{t}\end{array}$ & $\mathrm{AYP}=\mathrm{ht}$ & mus. $\mathrm{CB}$ & hollum. & cerebrum \\
\hline
\end{tabular}

did not expect a marked influence of $G_{p}$, as intracellular glucose levels were assumed to be below the apparent $K_{\mathrm{T}}$ of GLUT1. Translocation of GLUT1 to the plasma membrane at a low $G_{p}$ (8) would result in an increase in $k_{2}$ under hypoglycemia. This possibility was not supported by our data, although the high scattering in $k_{2}$ would not allow detection of minute changes.

Hexokinase type $\mathrm{I}$ is the major hexokinase isoform in the brain (33). The enzyme is saturated under normoglycemia, because $K_{\mathrm{M}}$ $(40 \mu \mathrm{mol} / \mathrm{L})$ is far below $\mathrm{G}_{\mathrm{i}}\left(>1 \mathrm{mmol} / \mathrm{L}\right.$ at $\left.\mathrm{G}_{\mathrm{p}}>5 \mathrm{mmol} / \mathrm{L}\right)$ $(29,34) \cdot \mathrm{G}_{\mathrm{p}}^{\prime}$ at the half maximal phosphorylation rate was 2.3 $\mathrm{mmol} / \mathrm{L}$. This value is close to the reported $\mathrm{G}_{\mathrm{p}}$ of $2 \mathrm{mmol} / \mathrm{L}$ in rats, at which intracellular glucose becomes depleted $(6,34)$. It appears plausible that in our experiments intracellular glucose levels reached the $K_{\mathrm{M}}$ of hexokinase $\mathrm{I}$ at a $\mathrm{G}_{\mathrm{p}}^{\prime}$ of $2.3 \mathrm{mmol} / \mathrm{L}$, resulting in an increase in $k_{3 \text {,glc }}$. Our simulation of $\mathrm{G}_{\mathrm{i}}$ in the cerebrum revealed that $G_{i}$ equals $149 \mu \mathrm{mol} / \mathrm{L}$ at a $\mathrm{G}^{\prime}{ }_{\mathrm{p}}$ of 2.3 $\mathrm{mmol} / \mathrm{L}$. $\mathrm{G}_{\mathrm{i}}$ was $40 \mu \mathrm{mol} / \mathrm{L}$ at a $\mathrm{G}^{\prime}{ }_{\mathrm{p}}$ of $1.3 \mathrm{mmol} / \mathrm{L}$. Taking into account the several assumptions made for this analysis and the uncertainty of the fits at a low $\mathrm{G}_{\mathrm{p}}{ }_{\mathrm{p}}$, our results support our hypothesis that the CBF increase and saturation kinetics alone can describe the physiologic responses to hypoglycemia in the mouse brain, including intracellular depletion of glucose at a $G_{p}$ of less than $2 \mathrm{mmol} / \mathrm{L}$.

One of our key findings is that both brain glucose transport and phosphorylation rate constants determined with ${ }^{18} \mathrm{~F}$-FDG PET depend on $G_{p}$. This finding is in agreement with predictions from theoretic analysis of the glia-vascular unit (1) and is supported by MR spectroscopy data (31) but is in contrast to other PET studies $(27,35)$. A main reason for the discrepancies from previous PET studies lies in the choice of the $\operatorname{LC}(13,14)$, in particular under hypoglycemia. The influence of $\mathrm{G}_{\mathrm{p}}$ was different on $K_{1, \mathrm{FDG}}$ and $k_{3, \text { FDG }}$. As $\mathrm{CMR}_{\mathrm{glc}}$ depends on both parameters, LC is not a constant but is dependent on $\mathrm{G}_{\mathrm{p}}$. Determining $K_{1, \mathrm{FDG}}-k_{3, \mathrm{FDG}}$ helps to avoid misinterpretations of ${ }^{18} \mathrm{~F}-\mathrm{FDG}$ PET results by comparing $\mathrm{CMR}_{\text {glc }}$ values calculated with inaccurate LC values. LC3 (28) allows $\mathrm{G}_{\mathrm{p}}$-dependent $\mathrm{LC}$ values, provided that species-specific $\mathrm{L}_{1}$ to $\mathrm{L}_{3}$ is available. However, $\mathrm{L}_{1}$ should be defined as $\mathrm{PS}_{\mathrm{FDG}} / \mathrm{PS}_{\mathrm{glc}}$ to take into account the influence of $\mathrm{CBF}$ on $K_{1, \mathrm{FDG}} / K_{1, \mathrm{glc}}$, as this ratio approaches 1 when $\mathrm{CBF}$ becomes rate-limiting. Alternatively, and to validate LC3, experimentally determined LC values are required for mice over a broad $\mathrm{G}_{\mathrm{p}}$ range, as done thus far in awake rats (LC2) (13).

The ratio $\mathrm{T}_{\max } / \mathrm{CMR}_{\mathrm{glc}}$ was constant under euglycemia in various nuclear magnetic resonance experiments. In rats anesthetized with $\alpha$-chloralose and enflurane, the ratio was 4.5-4.7 and 5.8, respectively, estimated with the irreversible Michaelis-Menten model $(6,31) . \mathrm{T}_{\max } / \mathrm{CMR}_{\mathrm{glc}}$ in mouse cerebrum in our study was 4.2 (LC2) and 4.1 (LC3), respectively, which is in the range of published values for rats.

We found a peculiar pattern for glucose transport in the hypothalamus. Both $K_{1, \mathrm{glc}}{ }^{-}$and $\mathrm{T}_{\mathrm{glc}}-\mathrm{versus}-\mathrm{G}_{\mathrm{p}}^{\prime}$ plots indicated a transport mechanism with either high $K_{\mathrm{T}}$ or absence of saturability within the studied $G_{p}$ range. At high but not low $G_{p}$, this finding is in line with reports of a less restrictive BBB for glucose in this brain region (34). Our high $K_{\mathrm{T}}$ would be in agreement with the reported presence of GLUT2 in the hypothalamus (36). The $K_{\mathrm{T}}$ of GLUT2 is around $17 \mathrm{mmol} / \mathrm{L}$ (37). However, the contribution of GLUT2 to overall glucose transport in the hypothalamus is not

TABLE 2

Post Hoc Tests of Repeated-Measures Variance Analysis

\begin{tabular}{|c|c|c|c|c|}
\hline \multirow[b]{2}{*}{$\mathrm{G}_{\mathrm{p}}$} & \multicolumn{2}{|c|}{ HYP minus average } & \multicolumn{2}{|c|}{ CTX minus average } \\
\hline & $K_{1, \mathrm{FDG}}$ & $K_{\mathrm{FDG}}$ & $K_{1, \mathrm{FDG}}$ & $K_{\mathrm{FDG}}$ \\
\hline$>2.5 \mathrm{mmol} / \mathrm{L}$ & $-0.017 \pm 0.046$ & $-0.007 \pm 0.008$ & $-0.007 \pm 0.017$ & $-0.009 \pm 0.008$ \\
\hline$<2.5 \mathrm{mmol} / \mathrm{L}$ & $-0.063 \pm 0.060^{\star}$ & $-0.035 \pm 0.015^{\dagger}$ & $-0.047 \pm 0.067^{\star}$ & $-0.028 \pm 0.015^{\dagger}$ \\
\hline \multicolumn{5}{|l|}{$\begin{array}{l}{ }^{*} P<0.05 \\
{ }^{\dagger} P<0.0002\end{array}$} \\
\hline
\end{tabular}




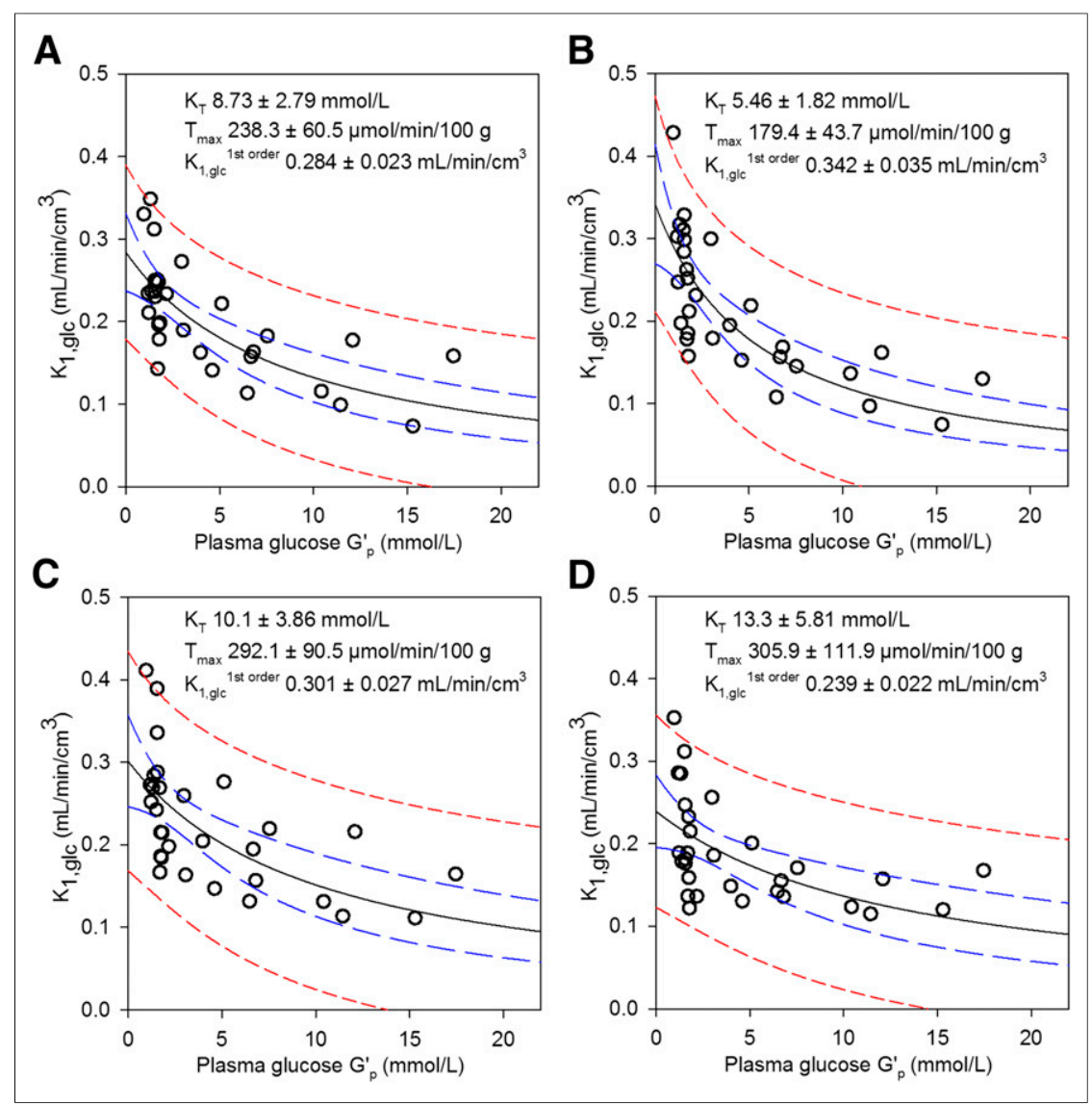

FIGURE 5. Influence of $G_{p}$ on $K_{1, \text { glc }}$ in cortex (A), striatum (B), cerebellum (C), and hypothalamus (D). Lines as in Figure 2A. Values at $G_{p}$ of less than $2.0 \mathrm{mmol} / \mathrm{L}$ were corrected for expected increase in CBF by $57 \%$. Hippocampus and thalamus, as well as $\mathrm{T}_{\text {glc }}$ vs. $\mathrm{G}_{\mathrm{p}}$, are presented in Supplemental Figures 12 and 13. $R^{2}=0.524(\mathrm{~A}), 0.589(\mathrm{~B}), 0.399(\mathrm{C})$, and $0.289(\mathrm{D})$. Solid black line = fit with Equation 6 (fit parameters ingraph); dashed blue lines $=95 \%$ confidence band; dashed red lines $=95 \%$ prediction band.

known. Under hypoglycemia, glucose transport was lowest in the hypothalamus as judged from $K_{1, \mathrm{glc}}{ }^{1 \text { st }}$ order and $K_{1, \mathrm{glc}}$. However, the absolute numbers of the regional analysis must be interpreted with caution considering the strong scattering in the data, spillover, and partial-volume effects.

Decreased ${ }^{18}$ F-FDG uptake in the hypothalamus was also observed in humans under hypoglycemia (38). Both observations of high transport at high $\mathrm{G}_{\mathrm{p}}$ and low transport at low $\mathrm{G}_{\mathrm{p}}$, with the resulting effects on $\mathrm{G}_{\mathrm{i}}$ as simulated in this study, are of interest in the context of the suggested mechanism of glucose sensing in the hypothalamus by an intracellular glucose-binding sequence of GLUT2 $(9,39)$. Signaling could be effective at both extremes of $G_{p}$.

We cannot exclude a pharmacologic influence of insulin on the measured parameters. Insulin increases cortical blood flow in rats at doses of $120 \mathrm{ng} / \mathrm{mL}$ in superfused cerebral spinal fluid (40). We may induce similar insulin levels in cerebral vessels. However, our dataset included a hypoglycemic animal without insulin treatment and a normoglycemic one that received a lower insulin dose. Both datasets were in agreement with the others. Horinaka et al. (25) showed that insulin administered under euglycemia had no effects on CBF, and previous studies suggested no direct influence of insulin on $K_{\mathrm{FDG}}$ (35). Isoflurane anesthesia has a significant influence on cerebral glucose metabolism. Our findings,

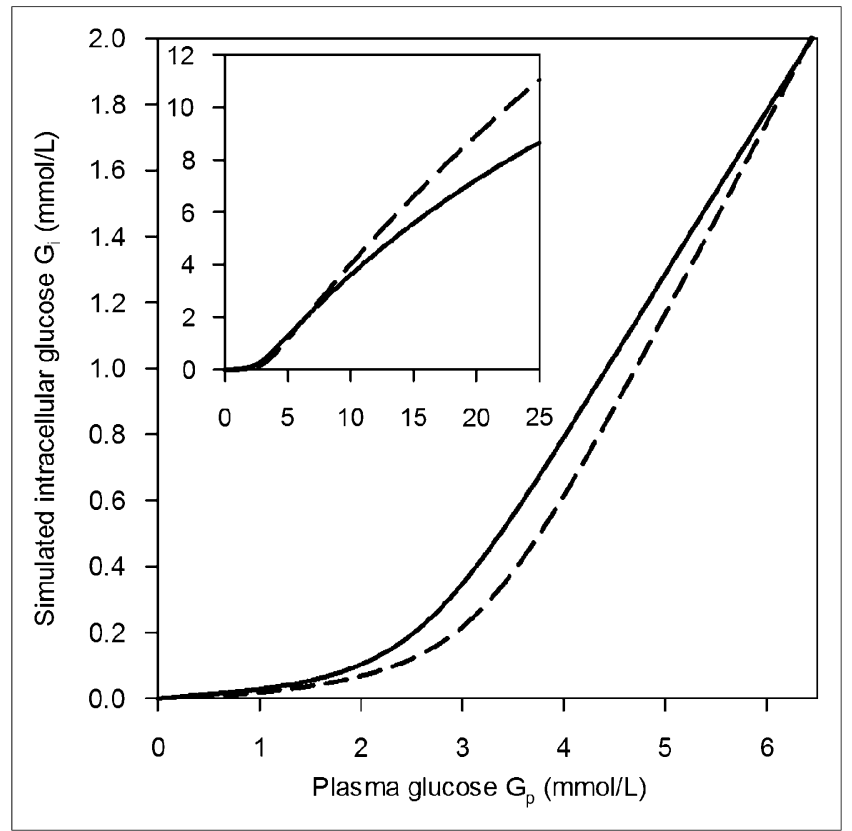

FIGURE 6. Intracellular glucose concentrations of cerebrum (solid line) and hypothalamus (dashed line) simulated as functions of $G_{p}$ from fit parameters for transport and phosphorylation. Inset shows extended $G_{p}$ range. therefore, cannot be directly translated to awake mice or mice under different anesthesia.

\section{CONCLUSION}

Glucose plasma-to-brain clearance and phosphorylation rate constant were increased under hypoglycemia. The alterations, including intracellular depletion of glucose, can be quantitatively described taking into account increased CBF and saturation kinetics of GLUT and hexokinase. In contrast to other brain regions, glucose transport in the hypothalamus did not show significant saturation and was lower under hypoglycemia but higher at a high $G_{p}$ than in other brain regions. This could contribute to the reported glucose-sensing function of the hypothalamus.

\section{DISCLOSURE}

The costs of publication of this article were defrayed in part by the payment of page charges. Therefore, and solely to indicate this fact, this article is hereby marked "advertisement" in accordance with 18 USC section 1734. This work was supported by the Swiss National Competence Center for Biomedical Imaging (NCCBI) and in part by the Centre d'Imagerie BioMédicale (CIBM) of the UNIL, UNIGE, HUG, CHUV, EPFL, and the Leenaards and Jeantet Foundations. No other potential conflict of interest relevant to this article was reported. 


\section{ACKNOWLEDGMENTS}

We thank Alfred Buck, Bruno Weber, and Matthias T. Wyss (University of Zurich, Switzerland) for fruitful discussions.

\section{REFERENCES}

1. Barros LF, Bittner CX, Loaiza A, Porras OH. A quantitative overview of glucose dynamics in the gliovascular unit. Glia. 2007;55:1222-1237.

2. Kumagai AK, Kang YS, Boado RJ, Pardridge WM. Upregulation of blood-brain barrier GLUT1 glucose transporter protein and mRNA in experimental chronic hypoglycemia. Diabetes. 1995;44:1399-1404.

3. Simpson IA, Appel NM, Hokari M, et al. Blood-brain barrier glucose transporter: effects of hypo- and hyperglycemia revisited. J Neurochem. 1999;72:238-247.

4. Uehara Y, Nipper V, McCall AL. Chronic insulin hypoglycemia induces GLUT-3 protein in rat brain neurons. Am J Physiol. 1997;272:E716-E719.

5. Lee DH, Chung MY, Lee JU, Kang DG, Paek YW. Changes of glucose transporters in the cerebral adaptation to hypoglycemia. Diabetes Res Clin Pract. 2000;47:15-23.

6. Choi IY, Lee SP, Kim SG, Gruetter R. In vivo measurements of brain glucose transport using the reversible Michaelis-Menten model and simultaneous measurements of cerebral blood flow changes during hypoglycemia. J Cereb Blood Flow Metab. 2001;21:653-663.

7. Pelligrino DA, Segil LJ, Albrecht RF. Brain glucose utilization and transport and cortical function in chronic vs. acute hypoglycemia. Am J Physiol. 1990;259: E729-E735.

8. Russo VC, Kobayashi K, Najdovska S, Baker NL, Werther GA. Neuronal protection from glucose deprivation via modulation of glucose transport and inhibition of apoptosis: a role for the insulin-like growth factor system. Brain Res. 2004;1009:40-53.

9. Stolarczyk E, Guissard C, Michau A, et al. Detection of extracellular glucose by GLUT2 contributes to hypothalamic control of food intake. Am J Physiol Endocrinol Metab. 2010;298:E1078-E1087.

10. Leturque A, Brot-Laroche E, Le Gall M. GLUT2 mutations, translocation, and receptor function in diet sugar managing. Am J Physiol Endocrinol Metab. 2009;296:E985-E992.

11. Osundiji MA, Hurst P, Moore SP, et al. Recurrent hypoglycemia increases hypothalamic glucose phosphorylation activity in rats. Metabolism. 2011;60: $550-556$.

12. Kuwabara H, Evans AC, Gjedde A. Michaelis-Menten constraints improved cerebral glucose metabolism and regional lumped constant measurements with $\left[{ }^{18}\right.$ F]fluorodeoxyglucose. J Cereb Blood Flow Metab. 1990;10:180-189.

13. Suda S, Shinohara M, Miyaoka M, Lucignani G, Kennedy C, Sokoloff L. The lumped constant of the deoxyglucose method in hypoglycemia: effects of moderate hypoglycemia on local cerebral glucose utilization in the rat. J Cereb Blood Flow Metab. 1990;10:499-509.

14. Schuier F, Orzi F, Suda S, Lucignani G, Kennedy C, Sokoloff L. Influence of plasma glucose concentration on lumped constant of the deoxyglucose method: effects of hyperglycemia in the rat. J Cereb Blood Flow Metab. 1990;10:765-773.

15. Weber B, Burger C, Biro P, Buck A. A femoral arteriovenous shunt facilitates arterial whole blood sampling in animals. Eur J Nucl Med Mol Imaging. 2002; 29:319-323.

16. Alf MF, Wyss MT, Buck A, Weber B, Schibli R, Krämer SD. Quantification of brain glucose metabolism by ${ }^{18} \mathrm{~F}$-FDG PET with real-time arterial and imagederived input function in mice. J Nucl Med. 2013;54:132-138.

17. Sokoloff L, Reivich M, Kennedy C, et al. The $\left[{ }^{14} \mathrm{C}\right]$ deoxyglucose method for the measurement of local cerebral glucose utilization: theory, procedure, and normal values in the conscious and anesthetized albino rat. J Neurochem. 1977;28: 897-916.

18. Chugh BP, Lerch JP, Yu LX, et al. Measurement of cerebral blood volume in mouse brain regions using micro-computed tomography. Neuroimage. 2009;47: 1312-1318.
19. Gredell JA, Turnquist PA, Maciver MB, Pearce RA. Determination of diffusion and partition coefficients of propofol in rat brain tissue: implications for studies of drug action in vitro. Br J Anaesth. 2004;93:810-817.

20. Hasselbalch SG, Knudsen GM, Holm S, Hageman LP, Capaldo B, Paulson OB. Transport of D-glucose and 2-fluorodeoxyglucose across the blood-brain barrier in humans. J Cereb Blood Flow Metab. 1996;16:659-666.

21. Sørensen M, Keiding S. New findings on cerebral ammonia uptake in HE using functional ${ }^{13} \mathrm{~N}$-ammonia PET. Metab Brain Dis. 2007;22:277-284.

22. Russell ES, Neufeld EF, Higgins CT. Comparison of normal blood picture of young adults from 18 inbred strains of mice. Proc Soc Exp Biol Med. 1951;78:761-766.

23. Maeda K, Mies G, Olah L, Hossmann KA. Quantitative measurement of local cerebral blood flow in the anesthetized mouse using intraperitoneal $\left[{ }^{14} \mathrm{C}\right]$ iodoantipyrine injection and final arterial heart blood sampling. J Cereb Blood Flow Metab. 2000;20:10-14.

24. Jay TM, Lucignani G, Crane AM, Jehle J, Sokoloff L. Measurement of local cerebral blood flow with $\left[{ }^{14} \mathrm{C}\right]$ iodoantipyrine in the mouse. J Cereb Blood Flow Metab. 1988;8:121-129.

25. Horinaka N, Artz N, Jehle J, Takahashi S, Kennedy C, Sokoloff L. Examination of potential mechanisms in the enhancement of cerebral blood flow by hypoglycemia and pharmacological doses of deoxyglucose. J Cereb Blood Flow Metab. 1997; 17:54-63.

26. Yu AS, Lin HD, Huang SC, Phelps ME, Wu HM. Quantification of cerebral glucose metabolic rate in mice using ${ }^{18} \mathrm{~F}-\mathrm{FDG}$ and small-animal PET. $\mathrm{J}$ Nucl Med. 2009;50:966-973.

27. Wong KP, Sha W, Zhang X, Huang SC. Effects of administration route, dietary condition, and blood glucose level on kinetics and uptake of ${ }^{18} \mathrm{~F}-\mathrm{FDG}$ in mice. J Nucl Med. 2011;52:800-807.

28. Backes H, Walberer M, Endepols H, et al. Whiskers area as extracerebral reference tissue for quantification of rat brain metabolism using ${ }^{18}$ F-FDG PET: application to focal cerebral ischemia. J Nucl Med. 2011;52:1252-1260.

29. Muzi M, Freeman SD, Burrows RC, et al. Kinetic characterization of hexokinase isoenzymes from glioma cells: implications for FDG imaging of human brain tumors. Nucl Med Biol. 2001;28:107-116.

30. Duarte JM, Gruetter R. Cerebral glucose transport and homeostasis. In: Choi IY, Gruetter R, eds. Neural Metabolism In Vivo. New York, NY: Springer; 2012: 655-673.

31. Duarte JM, Gruetter R. Characterization of cerebral glucose dynamics in vivo with a four-state conformational model of transport at the blood-brain barrier. J Neurochem. 2012;121:396-406.

32. Gjedde A. High- and low-affinity transport of D-glucose from blood to brain. J Neurochem. 1981;36:1463-1471.

33. Wilson JE. Isozymes of mammalian hexokinase: structure, subcellular localization and metabolic function. J Exp Biol. 2003;206:2049-2057.

34. Poitry-Yamate C, Lei H, Gruetter R. The rate-limiting step for glucose transport into the hypothalamus is across the blood-hypothalamus interface. J Neurochem. 2009; 109(suppl 1):38-45.

35. Kreissl MC, Stout DB, Wong KP, et al. Influence of dietary state and insulin on myocardial, skeletal muscle and brain [F]-fluorodeoxyglucose kinetics in mice. EJNMMI Res. 2011;1:8.

36. Arluison M, Quignon M, Nguyen P, Thorens B, Leloup C, Penicaud L. Distribution and anatomical localization of the glucose transporter 2 (GLUT2) in the adult rat brain: an immunohistochemical study. J Chem Neuroanat. 2004;28:117-136.

37. Uldry M, Thorens B. The SLC2 family of facilitated hexose and polyol transporters. Pflugers Arch. 2004;447:480-489.

38. Dunn JT, Cranston I, Marsden PK, Amiel SA, Reed LJ. Attenuation of amygdala and frontal cortical responses to low blood glucose concentration in asymptomatic hypoglycemia in type 1 diabetes: a new player in hypoglycemia unawareness? Diabetes. 2007;56:2766-2773.

39. Thorens B. Brain glucose sensing and neural regulation of insulin and glucagon secretion. Diabetes Obes Metab. 2011;13(suppl 1):82-88.

40. Katakam PV, Domoki F, Lenti L, et al. Cerebrovascular responses to insulin in rats. J Cereb Blood Flow Metab. 2009;29:1955-1967. 